\title{
Analisis Faktor-Faktor yang Mempengaruhi Dividend Payout Ratio pada Saham-Saham Indeks LQ45 di Bursa Efek Indonesia Tahun 2011-2017
}

\author{
Dewi Marina $^{1^{*}}$, Widi Hidayat ${ }^{2}$, Ake Wihadanto ${ }^{3}$ \\ ${ }^{1 *}$ Program Studi Magister Manajemen, Fakultas Ekonomi, Universitas Terbuka \\ ${ }^{2}$ Fakultas Ekonomi, Universitas Airlangga Surabaya \\ ${ }^{3}$ Fakultas Ekonomi, Universitas Terbuka Jakarta \\ E-mail: dewimarina222@gmail.com ${ }^{1 *}$
}

\begin{abstract}
ABSTRAK
Kegiatan para investor memiliki harapan dari investasi yang dilakukannya di pasar modal, yaitu dividen dan capital gain. Investor lebih menyukai dividen daripada capital gain karena dividen memberikan harapan sesuatu yang lebih pasti daripada mengandalkan pada perubahan harga saham. Informasi yang akurat untuk menilai kesehatan keuangan dan kinerja perusahaan adalah dari sisi likuiditas, solvabilitas dan profitabilitas perusahaan. Penelitian ini bertujuan melakukan analisis faktorfaktor yang memengaruhi Dividend Payout Ratio Pada Saham-Saham Indeks LQ45 di Bursa Efek Indonesia Tahun 2011 - 2017. Variabel independen yang digunakan dalam penelitian ini adalah Likuiditas (Current Ratio), Solvabilitas (Debt to Equity Ratio), dan Profitabilitas (Return on Asset), sedangkan variabel dependen adalah Dividen (Dividend Payout Ratio). Populasi penelitian adalah 87 emiten dan 14 sampel. Hasil uji hipotesis menunjukkan terhadap Dividen (Dividend Payout Ratio), bahwa Likuiditas (Current Ratio) secara parsial tidak berpengaruh, Solvabilitas (Debt to Equity Ratio) secara parsial berpengaruh negatif dan signifikan, dan Profitabilitas (Return on Asset) secara parsial berpengaruh positif dan signifikan
\end{abstract}

Kata kunci: Likuiditas (Current Ratio); Solvabilitas (Debt to Equity Ratio); Profitabilitas (Return on Asset); Dividen (Dividend Payout Ratio)

\begin{abstract}
Investors' activities have expectations of regulated investments in the capital market, namely dividends and capital gains. Investors prefer dividends to capital gains because dividends offer hope that something more certain depends on changes in stock prices. Accurate information for financial assessment and company performance in terms of liquidity, solvency and profitability of the company. This study studies analyzing the factors that influence the Dividend Payout Ratio in LQ45 Index Shares in the Indonesia Stock Exchange in 2011 2017. The independent variables used in this study are Liquidity, Solvency, Debt to Equity Ratio, and Profitability (Return on Asset), while the dependent variable is Dividend (Dividend Payout Ratio). The study population was 87 issuers and 14 samples. Hypothesis test results indicate Dividend (Dividend Payout Ratio), that Liquidity (Current Ratio) is partially non-binding, Solvency (Debt to Equity Ratio) partially, negatively and significantly influences, and Profitability (Return on Asset) partially has positive and significant effect.
\end{abstract}

Keyword: Liquidity (Current Ratio); Solvency (Debt to Equity Ratio); Profitability (Return on Asset); Dividends (Dividend Payout Ratio) 


\section{PENDAHULUAN}

Pengukuran perekonomian suatu negara dapat dilakukan dengan melihat tingkat perkembangan di pasar modal serta jenis sektor industri. Setiap investor di bursa efek akan mendapatkan dividen serta capital gain dari investasi yang diberikan. Gumanti (2013) menyatakan dividen sangat disukai investor dibandingkan dengan capital gain, suatu kepastian yang dijanjikan oleh dividen dibandingkan mengandalkan hal yang tidak pasti seperti perubahan harga saham.

Ang (1997) menyatakan aktivitas investasi akan menjumpai risiko serta ketidakpastian yang sulit untuk dilakukan prediksi oleh investor. Diperlukan informasi seperti laporan performance perusahaan dan petunjuk lainnya yang berkaitan dalam suatu negara seperti kondisi ekonomi dan politik. Pernyataan tersebut berbeda dengan teori yang dikemukakan Miller dan Modigliani. Mulyawan (2015) menyatakan teori M \& M yang merupakan dasar dari teori keuangan modern, mengakui pendanaan dan investasi tidak berhubungan sama sekali, sebagai contoh bahwa memakai utang atau sebaliknya tanpa memakai utang dalam pembayaran investasi perusahaan tidak ada pengaruhnya terhadap perubahan nilai yang ada di perusahaan.

Samosir (2017) mengemukakan Indeks LQ45 memiliki keunggulan diantaranya keanggotaan terdiri dari 45 perusahaan yang telah dipilih setelah melalui berbagai kriteria yaitu menempati top $95 \%$ berdasarkan total rata-rata tahunan nilai transaksi saham, top 90\% berdasarkan rata-rata tahunan kapitalisasi pasar, posisi tertinggi kapitalisasi pasar dengan masing-masing sektor usahanya dan urutan tertinggi berdasarkan frekuensi transaksi perdagangan. Parera (2016) mengemukakan emiten yang masuk dalam indeks LQ45 memiliki likuiditas yang baik dan telah dilakukan penyeleksian dengan beberapa kriteria untuk pemilihan. Tandelilin (2010) menyatakan indeks LQ45 dengan 45 saham di BEI yang merupakan likuiditas juga kapitalisasi tinggi yang lolos seleksi dari kriteria yang ditentukan.

Hanafi dan Halim (2014) menyatakan perusahaan yang mempunyai tingkat pertumbuhan yang tinggi akan mempunyai rasio pembayaran dividen yang rendah, sebaliknya perusahaan dengan tingkat pertumbuhan yang rendah akan mempunyai rasio pembayaran dividen yang tinggi. Pernyataan tersebut berbeda dengan teori yang dikemukakan Miller dan Modigliani. Mulyawan (2015) menyatakan Modigliani dan Miller berpendapat sesuai teori ketidakrelevanan dividen bahwa nilai suatu perusahaan tidak ditentukan oleh besar kecilnya Dividend Payout Ratio, tetapi ditentukan oleh laba bersih sebelum pajak dan kelas risiko perusahaan. Jadi dividen tidak relevan untuk diperhitungkan karena tidak memperhitungkan kesejahteraan pemegang saham. Kenaikan nilai perusahaan dipengaruhi oleh kemampuan 
perusahaan untuk mendapatkan keuntungan dari aset perusahaan. Sesuai teori signaling hypotesis, Mulyawan (2015) menyatakan penurunan dividen diyakini investor sebagai sinyal bahwa perusahaan akan menghadapi masa sulit di waktu mendatang.

Erni (2015) menyampaikan selain investor lebih menyukai dividen daripada capital gain, ada lagi yang lebih disukai oleh investor yaitu dividen yang dapat diprediksi. Faktor stabilitas dividen akan lebih menarik daripada Dividend Payout Ratio yang tinggi, karena investor menyakini penurunan dividen merupakan sinyal negatif mengenai prospek perusahaan di masa mendatang.

Secara teori, Mulyawan (2015) berpendapat salah satu pertimbangan utama dalam kebijakan dividen adalah likuiditas perusahaan. Dividen merupakan arus kas keluar dimana semakin besar jumlah kas yang tersedia serta seberapa likuiditasnya perusahaan maka semakin besar pula kemampuan sebuah perusahaan untuk melakukan pembayaran dividen. Secara empiris, pada penelitian Afrina (2014) serta Rehman dan Takumi (2012) menunjukkan bahwa Current Ratio mempunyai pengaruh positif signifikan terhadap Dividen Payout Ratio. Pada penelitian Laim, dkk (2015) menunjukkan bahwa Current Ratio secara parsial tidak berpengaruh terhadap Dividend Payout Ratio. Penelitian Putri (2017) menunjukkan bahwa Current Ratio secara parsial berpengaruh negatif signifikan terhadap Dividend Payout Ratio.

Secara empiris, pada penelitian Afrina (2014), Marlina dan Danica (2009), Laim, dkk (2015), Yunita dan Friskarunia (2016), serta Swastyastu, dkk (2014) menunjukkan bahwa Debt to Equity Ratio tidak mempunyai pengaruh signifikan terhadap Dividend Payout Ratio. Pada penelitian Rehman dan Takumi (2012) dan Samosir (2017) menunjukkan Debt to Equity Ratio secara parsial berpengaruh positif signifikan terhadap Dividend Payout Ratio. Penelitian Putri (2017) dan Parera (2016) menunjukkan Debt to Equity Ratio secara parsial berpengaruh negatif signifikan terhadap Dividend Payout Ratio.

Secara teori, menurut Sartono $(2010 ; 122)$ profitabilitas dapat mengetahui seberapa besar kemampuan perusahaan untuk mendapatkan pendapatan dari modal sendiri maupun total aktiva, dalam hubungannya hal ini dengan kegiatan penjualan. Menurut Mulyawan (2015) berpendapat bahwa semakin meningkatnya dana untuk kebutuhan perusahaan, maka kemampuan untuk membayar dividen semakin menurun. Secara empiris, pada penelitian Afrina (2014), Marlina dan Danica (2009), Yunita dan Friskarunia (2016), Rehman dan Takumi (2012), Putri (2017), serta Marpaung dan Hadianto (2009) menunjukkan bahwa Return on Asset mempunyai pengaruh positif dan signifikan terhadap Dividen Payout Ratio. Pada penelitian Laim, dkk (2015), Parera (2016), Swastyastu, dkk (2014), serta Ritha dan Koestiyanto (2013) menunjukkan bahwa Return on Asset mempunyai tidak mempunyai 
pengaruh terhadap Dividen Payout Ratio.

Berdasarkan uraian masalah yang ada dapat dimunculkan suatu hipotesis penelitian yaitu: Hipotesis $1\left(\mathrm{H}_{1}\right)$ diduga likuiditas (Current Ratio) secara parsial berpengaruh positif terhadap dividen (Dividend Payout Ratio) pada saham-saham indeks LQ45 di Bursa Efek Indonesia tahun 2011 - 2017. Hipotesis $2\left(\mathrm{H}_{2}\right)$ diduga solvabilitas (Debt to Equity Ratio) secara parsial berpengaruh negatif terhadap dividen (Dividend Payout Ratio) pada sahamsaham indeks LQ45 di Bursa Efek Indonesia tahun 2011 - 2017. Hipotesis $3\left(\mathrm{H}_{3}\right)$ diduga profitabilitas (Return on Asset) secara parsial berpengaruh positif terhadap dividen (Dividend Payout Ratio) pada saham-saham indeks LQ45 di Bursa Efek Indonesia tahun 2011 - 2017.

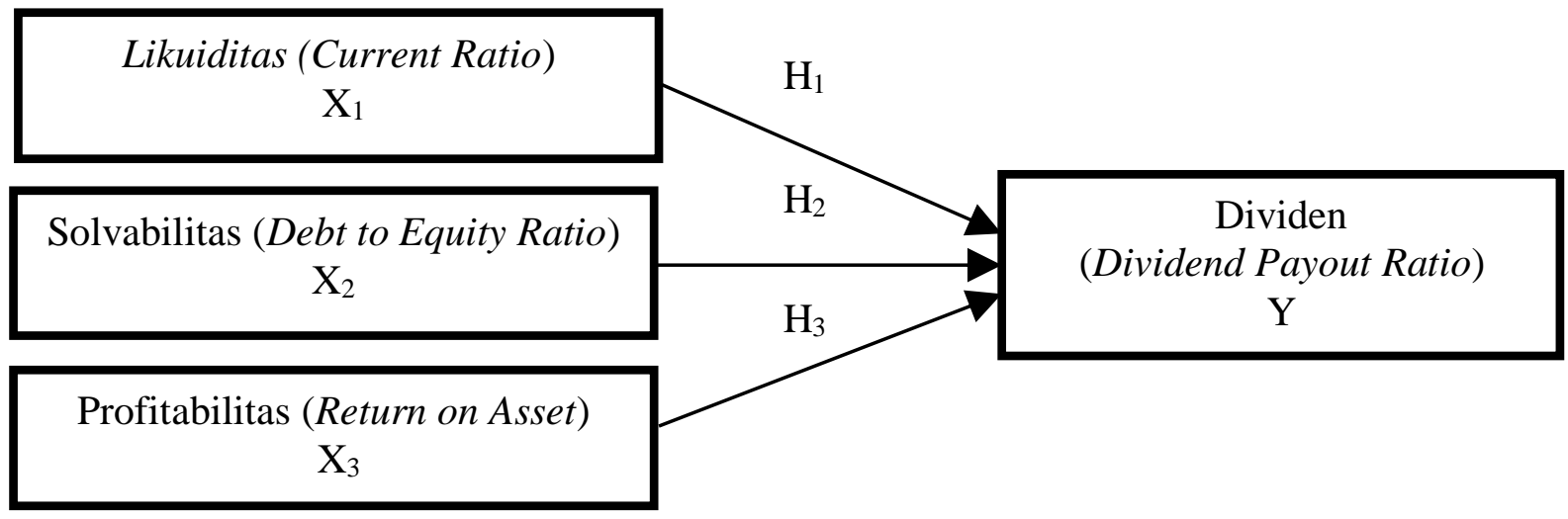

\section{Gambar 1. Hipotesis Penelitian}

Peneliti menggunakan skala rasio dalam melakukan penelitian. Data yang dihasilkan dari skala rasio disebut data rasio dan tidak ada pembatasan terhadap alat uji statistik yang sesuai. Variabel dependen dan independen dalam penelitian ini adalah likuiditas (Current Ratio) sebagai variabel independen, solvabilitas (Debt to Equity Ratio) sebagai variabel independen, profitabilitas (Return on Asset) sebagai variabel independen, dividen (Dividend Payout Ratio) sebagai variabel dependen.

\section{METODE PENELITIAN}

Metode yang digunakan dalam penelitian ini adalah menggunakan metode kuantitatif yaitu merupakan jenis penelitian dengan melakukan pengujian hipotesis atas pertanyaan yang diperoleh dari teori dan empiris dengan mengungkapkan instrumen untuk mengukur variabelvariabel, dengan maksud menganalisis kecil atau besarnya suatu pengaruh terhadap objek yang diteliti. Populasi penelitian ini adalah 87 emiten pada saham-saham indeks LQ45 yaitu 45 emiten setiap semesternya mulai semester 1 (Februari 2011-Juli 2011) sampai dengan semester 2 (Agustus 2017-Januari 2018) diharapkan dapat menghasilkan sampel yang cukup 
dan dapat digeneraliasi. Sampel yang dipilih untuk penelitian ini menggunakan metoda purposive sampling. Berdasarkan dari laporan keuangan perusahaan pada pada saham-saham indeks LQ45, seleksi sampel penelitian berdasarkan kriteria disajikan pada Tabel 1.

\section{Tabel 1. Kriteria Sampel Penelitian}

\begin{tabular}{|c|c|c|}
\hline No. & Kriteria Sampel & Jumlah \\
\hline 1. & $\begin{array}{l}\text { Perusahaan pada saham-saham indeks LQ45 yang terdaftar di BEI tahun } \\
2011 \text { - } 2017\end{array}$ & 87 \\
\hline 2. & $\begin{array}{l}\text { Perusahaan pada saham-saham indeks LQ45 yang terdaftar di BEI tujuh } \\
\text { tahun berturut-turut dari tahun } 2011-2017\end{array}$ & 21 \\
\hline & $\begin{array}{l}\text { Perusahaan pada saham-saham indeks LQ45yang membagikan dividen } \\
\text { tujuh tahun berturut-turut dari tahun } 2011-2017\end{array}$ & 14 \\
\hline
\end{tabular}

Seleksi sampel penelitian berdasarkan kriteria menunjukkan bahwa dari 87 emiten pada saham-saham indeks LQ45 yang terdaftar di BEI dari tahun 2011 - 2017 hanya terpilih 14 emiten yang akan digunakan sebagai sampel penelitian.

Jenis instrumen penelitian yang digunakan dalam penelitian ini adalah dokumentasi, jenis data menggunakan data dokumenter, sumber data menggunakan data sekunder berupa laporan keuangan perusahaan sampel yang meliputi rasio likuiditas (Current Ratio), rasio solvabilitas (Debt to Equity Ratio) dan profitabilitas (Return on Asset) dan dividen (Dividend Payout Ratio) pada saham-saham indeks LQ45 Bursa Efek Indonesia tahun 2011 - 2017 dengan mengunduh data dari situs resmi Bursa Efek Indonesia (BEI) pada saham-saham indeks LQ45 di laporan keuangan periode tahun 2011 - 2017 di Indonesia Stock Exchange.

Program aplikasi SPSS digunakan dalam penelitian. Peneliti menggunakan statistik deskriptif untuk memberikan informasi karakteristik variabel penelitian khususnya mengenai mean dan deviasi standar. Pengukuran mean merupakan cara yang paling umum digunakan untuk mengukur nilai sentral dari suatu distribusi data.

Uji asumsi klasik merupakan cara untuk mengetahui apakah model regresi yang diperoleh dapat menghasilkan estimator linier yang baik. Sebelum melakukan uji statistik, peneliti melakukan screening terhadap data yang akan diolah. Uji normalitas digunakan untuk melakukan pengujian bagaimana dalam model regresi, variabel pengganggu atau residual memiliki distribusi normal. Uji multikolinieritas bertujuan menguji apakah model regresi ditemukan adanya korelasi antar variabel bebas (independen). Untuk mendeteksi adanya atau tidaknya multikolinieritas di dalam model regresi adalah dengan melihat Variance Inflation Factor (VIF). Uji Heteroskedastisitas digunakan untuk mengetahui apakah dalam model 
regresi terjadi perbedaan variance dari residual satu pengamatan ke pengamatan yang lain. Regresi yang baik adalah yang tidak terjadi heterokedastisitas atau yang homoskedastisitas. Uji autokorelasi digunakan sebagai pengujian apakah regresi linier ada korelasi antara kesalahan pengganggu. Metode analisis menggunakan regresi. Regresi linier berganda dinilai sebagai model yang baik apabila model tersebut terbebas dari asumsi-asumsi klasik statis. Model persamaan regresi secara umum:

$$
Y_{\text {it }}=a+\beta_{1} X_{1 \text { it }}+\beta_{2} X_{2 \text { it }}+\beta_{3} X_{3 \text { it }}+e
$$

Keterangan:

$$
\begin{array}{ll}
\mathrm{Y} & =\text { Dividen (Dividend Payout Ratio) } \\
\text { it } & =\text { Dividen selama periode } \mathrm{t} \\
\mathrm{a} & =\text { Konstanta } \\
\mathrm{X}_{1} & =\text { Likuiditas (Current Ratio) } \\
\mathrm{X}_{2} & =\text { Solvabilitas (Debt to Equity Ratio) } \\
\mathrm{X}_{3} & =\text { Profitabilitas (Return on Asset) } \\
\beta_{1}, \beta_{2}, \beta_{3} & =\text { Koefisien Regresi } \\
\mathrm{e} & =\text { Standart Error }
\end{array}
$$

Uji statistik t pada dasarnya menunjukkan seberapa jauh pengaruh satu variabel penjelas (independen) secara individual dalam menerangkan variasi variabel dependen. Pengujian hipotesis dalam penelitian ini dengan menggunakan uji $t$ untuk menguji variabel independen terhadap variabel dependen.

\section{HASIL DAN PEMBAHASAN}

Populasi sampel dalam penelitian ini merupakan perusahaan pada saham-saham indeks LQ45 yang terdaftar di Bursa Efek Indonesia dari tahun 2011 - 2017. Daftar sampel penelitian yang telah dikelompokkan berdasarkan jenis usahanya tertuang dalam Tabel 2.

Tabel 2. Daftar Perusahaan Sampel Penelitian

\begin{tabular}{clcl}
\hline NO & \multicolumn{1}{c}{ NAMA PERUSAHAAN } & NO & \multicolumn{1}{c}{ NAMA PERUSAHAAN } \\
\hline 1 & Astra International Tbk. & 8 & Unilever Indonesia Tbk. \\
2 & Bank Central Asia Tbk. & 9 & Indofood Sukses Makmur Tbk. \\
3 & Bank Negara Indonesia (Persero) Tbk. & 10 & Kalbe Farma Tbk. \\
4 & Bank Rakyat Indonesia (Persero) Tbk. & 11 & Adaro Energy Tbk. \\
5 & Bank Mandiri (Persero) Tbk. & 12 & PP London Sumatera Tbk. \\
6 & Indocement Tunggal Prakasa Tbk. & 13 & Gudang Garam Tbk. \\
7 & Tambang Batubara BA (Persero) Tbk. & 14 & United Tractors Tbk. \\
\hline
\end{tabular}






Gambar 2. Prosetase Perusahaan Sampel Penelitian Berdasarkan Jenis Usaha Sumber : idx.co.id (data diolah)

Dapat dilihat pada Gambar 2 bahwa jenis usaha terbesar yang sesuai dengan kriteria sampel penelitian adalah pada jenis perbankan yaitu sebanyak 4 (empat) emiten atau sebesar $29 \%$, diartikan rata-rata jenis perbankan mempunyai kondisi keuangan perusahaan dan prospek pertumbuhan perusahaan yang lebih baik dibandingkan jenis usaha lainnya. Sedangkan emiten lainnya merupakan perusahaan yang mempunyai kondisi keuangan yang baik dibidangnya.

Data yang digunakan untuk setiap variabel penelitian berjumlah 98 yang diperoleh dari 14 perusahaan dikalikan periode tahun pengamatan (7 tahun). Dibawah ini disajikan hasil pengujian statistik deskriptif dalam Tabel 3.

Tabel 3. Statistik Deskriptif

\begin{tabular}{lccccc}
\hline & N & Minimum & Maximum & Mean & Std. Deviation \\
\hline DPR & 98 & 7.53 & 138.55 & 45.8992 & 22.12588 \\
\hline CR & 98 & 25.39 & 698.54 & $2.0180 \mathrm{E} 2$ & 142.65062 \\
\hline DER & 98 & 13.00 & 843.00 & $2.3896 \mathrm{E} 2$ & 269.46682 \\
\hline ROA & 98 & 1.41 & 71.51 & 11.1560 & 11.24057 \\
\hline Valid N (listwise) & 98 & & & & \\
\hline
\end{tabular}

Rata-rata perolehan Current Ratio (CR) adalah sebesar 2,0180\% dari Current Ratio (CR) yang dicapai perusahaan. Nilai maksimum sebesar 698,54 yang berarti bahwa Current Ratio (CR) tertinggi sebesar 698,54\% dari Current Ratio (CR) yang dicapai PT Indocement Putra Prakasa pada tahun 2011. Sedangkan nilai minimal Current Ratio (CR) sebesar 25,39 yang berarti bahwa Current Ratio (CR) terendah sebesar 25,39\% dari Current Ratio (CR) yang dicapai PT Bank Mandiri Indonesia pada tahun 2016.

Rata-rata perolehan Debt to Equity Ratio (DER) adalah sebesar 2,3896\% dari Debt to Equity Ratio (DER) yang dicapai perusahaan. Nilai maksimum sebesar 843 yang berarti 
bahwa Debt to Equity Ratio (DER) tertinggi sebesar 843\% dari Debt to Equity Ratio (DER) yang dicapai PT Bank Rakyat Indonesia pada tahun 2011. Sedangkan nilai minimal Debt to Equity Ratio (DER) sebesar 13 yang berarti bahwa Debt to Equity Ratio (DER) terendah sebesar 13\% dari Debt to Equity Ratio (DER) yang dicapai PT Indocement Tunggal Prakasa pada tahun 2016 .

Rata-rata perolehan Return on Asset Ratio (ROA) adalah sebesar 11,24057\% dari Return on Asset Ratio (ROA) yang dicapai perusahaan. Nilai maksimum sebesar 71,51 yang berarti bahwa Return on Asset Ratio (ROA) tertinggi sebesar 71,51\% dari Return on Asset Ratio (ROA) yang dicapai PT Unilever Indonesia pada tahun 2013. Sedangkan nilai minimal Return on Asset Ratio (ROA) sebesar 1,41 yang berarti bahwa Return on Asset Ratio (ROA) terendah sebesar $1,41 \%$ dari Return on Asset Ratio (ROA) yang dicapai PT Bank Mandiri Indonesia pada tahun 2016.

Rata-rata perolehan Dividend Payout Ratio (DPR) adalah sebesar 45,8992\% dari Dividend Payout Ratio (DPR) yang dicapai perusahaan. Nilai maksimum sebesar 138,55 yang berarti bahwa Dividend Payout Ratio (DPR) tertinggi sebesar 138,55\% dari Dividend Payout Ratio (DPR) yang dicapai PT Indocement Tunggal Prakasa pada tahun 2017. Sedangkan nilai minimal Dividend Payout Ratio (DPR) sebesar 7,53 yang berarti bahwa Dividend Payout Ratio (DPR) terendah sebesar 7,53\% dari Dividend Payout Ratio (DPR) yang dicapai PT Bank Central Asia Indonesia pada tahun 2016.

Peneliti menggunakan uji statistik non-parametrik Kolmogrov-Smirnov (K-S). Uji normalitas disyaratkan dengan data berdistribusi normal apabila probabilitas asymp.sig (2tailed $)>0,05$. Berikut ini disajikan hasil uji normalitas dalam Tabel 4.

Tabel 4. Uji Normalitas

\begin{tabular}{llr}
\hline & & Unstandardized Residual \\
\hline $\mathrm{N}$ & & 98 \\
Normal Parameters & & \\
& Mean & .0000000 \\
& Std. Deviation & 17.60956582 \\
Most Extreme & Absolute & .131 \\
Differences & Positive & .131 \\
& Negative & -.072 \\
Kolmogorov-Smirnov Z & 1.301 \\
Asymp. Sig. (2-tailed) & .068 \\
\hline
\end{tabular}

Disimpulkan bahwa angka signifikansi lebih besar dari 0,05 atau 5\% yang menandakan data yang diteliti berdistribusi normal dan dapat dilanjutkan untuk dilakukan penelitian. 
Data penelitian baik apabila antara varabel bebas yang satu dengan variabel bebas yang lain dalam model regresi terjadi hubungan yang mendekati sempurna. Berikut ini disajikan hasil uji normalitas dalam Tabel 5.

Tabel 5. Uji Multikolinearitas

\begin{tabular}{|c|c|c|c|c|c|c|c|c|}
\hline & \multirow[b]{2}{*}{ Model } & \multicolumn{2}{|c|}{$\begin{array}{c}\text { Unstandardized } \\
\text { Coefficients }\end{array}$} & \multirow{2}{*}{$\begin{array}{c}\begin{array}{c}\text { Standarized } \\
\text { Coefficients }\end{array} \\
\text { Beta } \\
\end{array}$} & \multirow[b]{2}{*}{$\mathbf{t}$} & \multirow[b]{2}{*}{ Sig. } & \multicolumn{2}{|c|}{ Collinearity Statistics } \\
\hline & & $\mathbf{B}$ & Std. Error & & & & Tolerance & VIF \\
\hline \multirow[t]{4}{*}{1} & (Constant) & 44.807 & 5.784 & & 7.746 & .000 & & \\
\hline & $\mathrm{CR}$ & -.014 & .016 & -.089 & -.860 & .392 & .633 & 1.580 \\
\hline & DER & -.025 & .009 & -.310 & -2.839 & .006 & .565 & 1.771 \\
\hline & ROA & .892 & .175 & .453 & 5.109 & .000 & .856 & 1.168 \\
\hline
\end{tabular}

Disimpulkan bahwa tidak ditemukan adanya gejala korelasi yang kuat antara sesama variabel bebas. Semua nilai VIF yang dihitung lebih kecil dari 10 dan nilai tolerance diatas 0,1. Penelitian ini tidak terdapat multikolinieritas diantara variabel bebas.

Model regresi yang baik adalah yang tidak terjadi heterokedastisitas atau homoskedastisitas. Sedangkan apabila terdapat gejala varians sama disebut homokedastisitas. Berikut ini disajikan hasil uji heteroskedastisitas dalam Gambar 3.

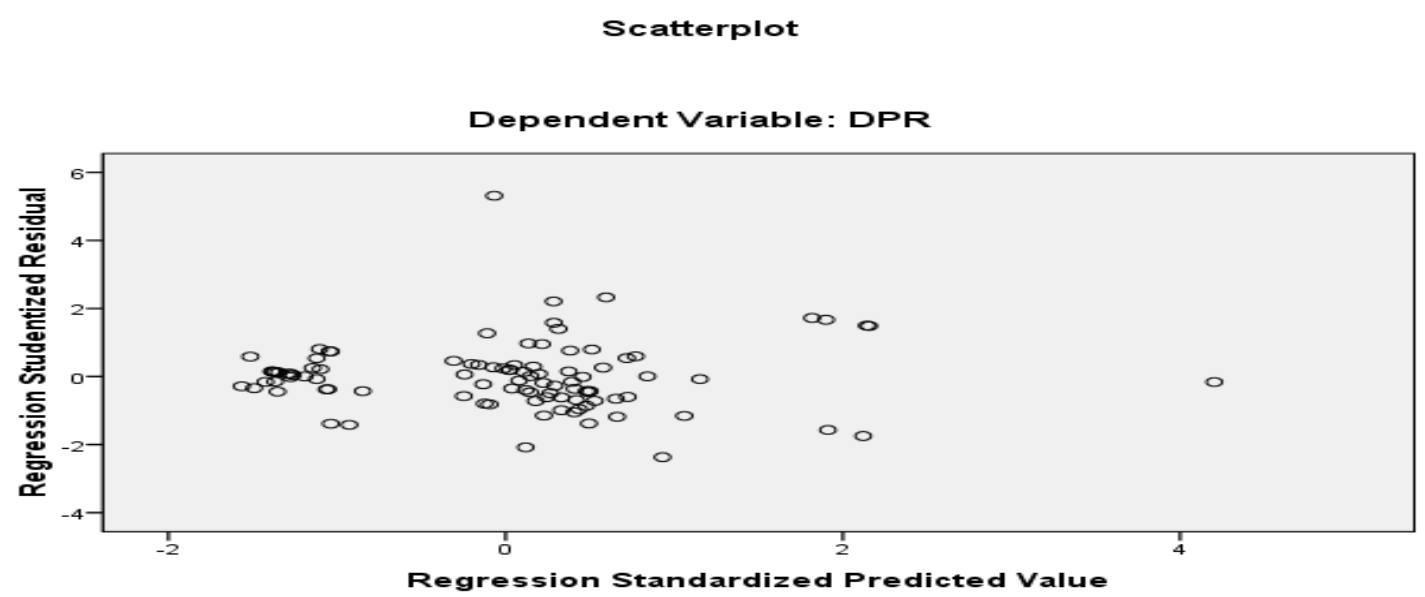

Gambar 3. Uji Heteroskedastisitas

Disimpulkan bahwa Plot yang menyebar dan tidak membentuk suatu pola tertentu, sehingga dapat disimpulkan data tidak terjadi masalah heteroskedastisitas. Analisis grafik plot memiliki kelemahan yang cukup signifikan oleh karena jumlah pengamatan memengaruhi hasil ploting, untuk itu diperlukan uji statistik yang lebih dapat menjamin keakuratan hasil, salah satunya yaitu menggunakan uji Glejser. Berikut ini disajikan hasil uji glejser dalam Tabel 6. 
Tabel 6. Uji Glejser

\begin{tabular}{|c|c|c|c|c|c|c|c|}
\hline \multirow{2}{*}{\multicolumn{2}{|c|}{ Model }} & \multicolumn{2}{|c|}{ Unstandardized Coefficients } & \multirow{2}{*}{\multicolumn{2}{|c|}{$\begin{array}{c}\begin{array}{c}\text { Standardized } \\
\text { Coefficients }\end{array} \\
\text { Beta } \\
\end{array}$}} & \multirow[b]{2}{*}{ 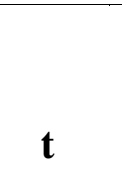 } & \multirow[b]{2}{*}{ Sig. } \\
\hline & & $\mathbf{B}$ & Std. Error & & & & \\
\hline 1 & (Constant) & 9.515 & 4.009 & & & 2.374 & .020 \\
\hline & $\mathrm{CR}$ & .008 & .011 & & .092 & .756 & .451 \\
\hline & DER & -.007 & .006 & & -.151 & -1.169 & .245 \\
\hline & ROA & .215 & .121 & & .187 & 1.779 & .078 \\
\hline
\end{tabular}

Berdasarkan uji heteroskedastisitas dengan metode Glesjer diperoleh nilai t hitung lebih kecil t tabel $(1,9908)$ dan nilai signifikansi lebih besar 0,05 yaitu CR sebesar 0,451, DER sebesar 0,245, ROA sebesar 0,078 sehingga dapat disimpulkan data tidak terjadi masalah heteroskedastisitas Observasi yang berurutan sepanjang waktu berkaitan satu sama lain akan terjadi autokorelasi. Berikut ini disajikan hasil uji autokorelasi dalam Tabel 7.

Tabel 7. Uji Autokorelasi

\begin{tabular}{lrrrrrr}
\hline Model & R & R Square & $\begin{array}{c}\text { Adjusted R } \\
\text { Square }\end{array}$ & $\begin{array}{c}\text { Std. Error of the } \\
\text { Estimate }\end{array}$ & Durbin-Watson \\
\hline 1 & $.605^{\mathrm{a}}$ & .367 & .346 & 17.88836 & 1.612 \\
\hline
\end{tabular}

Berdasarkan tabel diatas nilai Durbin-Watson diperoleh angka 1,612. Hal tersebut terlihat dari nilai DW sebesar 1,612 yang berada diantara batas bawah 1,490 dan batas atas 2,510 atau $1,490<1,612<2,510$ yang berarti tidak terdapat autokorelasi

Regresi linear berganda digunakan sebagai pendeteksi pengaruh signifikan atau tidak signifikan variabel independen yang diteliti terhadap dependen. Pengujian analisis regresi dapat dilihat pada tabel 8. Dapat disebut model yang baik dalam regresi linier berganda apabila model tersebut tidak terdapat asumsi-asumsi klasik statis. Rumus yang digunakan sebagai model persamaan regresi adalah, $Y_{\text {it }}=a+\beta_{1} X_{1 \text { it }}+\beta_{2} X_{2}$ it $+\beta_{3} X_{3 \text { it }}+$ e.

Model regresi linear berganda diatas dapat dibentuk dari variabel yang ada dan dapat diformulasikan dalam model persamaan sebagai berikut: DPR $=44,807-0,014 \mathrm{CR}-0,025$ DER + 0,892 ROA.

Korelasi berganda $(\mathrm{R})$ digunakan untuk mengetahui seberapa besar keeratan hubungan antara variabel independen dengan variabel dependen, sedangkan analisis koefisien determinasi (adjusted R2) menunjukkan seberapa besar variabel independen mampu menerangkan variabel dependen. Hasil analisis dapat dilihat pada Tabel 9. 
Tabel 8. Analisis Regresi

\begin{tabular}{|c|c|c|c|c|c|c|}
\hline \multirow{2}{*}{\multicolumn{2}{|c|}{ Model }} & \multicolumn{2}{|c|}{ Unstandardized Coefficients } & \multirow{2}{*}{$\frac{\text { Standardized Coefficients }}{\text { Beta }}$} & \multirow[b]{2}{*}{$\mathbf{t}$} & \multirow[b]{2}{*}{ Sig. } \\
\hline & & B & Std. Error & & & \\
\hline 1 & (Constant) & 44.807 & 5.784 & & 7.746 & .000 \\
\hline & $\mathrm{CR}$ & -.014 & .016 & -.089 & -.860 & .392 \\
\hline & DER & -.025 & .009 & -.310 & -2.839 & .006 \\
\hline & ROA & .892 & .175 & .453 & 5.109 & .000 \\
\hline
\end{tabular}

Tabel 9. Analisis Korelasi dan Koefisien Determinasi

\begin{tabular}{|c|c|c|c|c|}
\hline Model & $\mathrm{R}$ & R Square & Adjusted R Square & Std. Error of the Estimate \\
\hline 1 & $.605^{\mathrm{a}}$ & .367 & .346 & 17.88836 \\
\hline
\end{tabular}

Hasil analisis korelasi berganda (R) adalah sebesar 0,605 atau 60,5\% menunjukkan keeratan hubungan antara variabel CR, DR, dan ROA terhadap DPR. Hasil analis koefisien determinasi (adjusted R2) sebesar 0,346. Ini berarti 34,6\% variasi dari DPR dijelaskan oleh CR, DR, dan ROA. Seluruh variabel independen mampu menerangkan variabel dependen sebesar 34,6\% dan sisanya 65,4\% dijelaskan oleh faktor-faktor lain diluar penelitian.

Pengujian parsial atau uji t dilakukan dalam rangka mengetahui bagaimana pengaruh individual penitian dari suatu variabel independen (variabel $\mathrm{X}$ ) terhadap variabel dependen (variabel Y). Hasil pengujian hipotesis dapat dilihat pada Tabel 10.

\section{Tabel 10. Pengujian Hipotesis Uji t}

\begin{tabular}{|c|c|c|c|c|c|}
\hline \multirow[b]{2}{*}{ Model } & \multicolumn{2}{|c|}{ Unstandardized Coefficients } & \multirow{2}{*}{$\begin{array}{c}\text { Standardized } \\
\text { Coefficients }\end{array}$} & \multirow[b]{2}{*}{$\mathbf{t}$} & \multirow[b]{2}{*}{ Sig. } \\
\hline & B & Std. Error & & & \\
\hline 1 (Constant) & 44.807 & 5.784 & & 7.746 & .000 \\
\hline $\mathrm{CR}$ & -.014 & .016 & -.089 & -.860 & .392 \\
\hline DER & -.025 & .009 & -.310 & -2.839 & .006 \\
\hline ROA & .892 & .175 & .453 & 5.109 & .000 \\
\hline
\end{tabular}

\section{Hipotesis 1}

Hasil pengujian hipotesis pada tabel 10, pengujian menunjukkan bahwa nilai t hitung sebesar $-0,860<$ nilai t tabel sebesar 1,7709 dan nilai signifikasi lebih besar dari $5 \%$ yaitu sebesar 0,392\% maka $\mathrm{H}_{0}$ diterima dan $\mathrm{H}_{\mathrm{a}}$ ditolak. Dapat disimpulkan bahwa Current Ratio secara parsial tidak berpengaruh terhadap DPR. Tanda negatif yang terdapat pada koefisien regresi menunjukkan bahwa setiap peningkatan nilai $\mathrm{CR}$ akan menyebabkan menurunnya nilai Dividend Payout Ratio sebesar 0,014 satuan. Konstanta sebesar 44,807 menyatakan bahwa jika CR bernilai konstan maka besarnya DPR adalah sebesar 44,807. 


\section{Hipotesis 2}

Hasil pengujian hipotesis pada tabel 10, pengujian menunjukkan bahwa nilai t hitung sebesar $-2,839$ < nilai t tabel sebesar 1,7709 dan nilai signifikasi lebih kecil dari 5\% yaitu sebesar 0,006\% maka $\mathrm{H}_{0}$ ditolak dan $\mathrm{H}_{\mathrm{a}}$ diterima. Dapat disimpulkan bahwa Debt to Equity Ratio secara parsial berpengaruh negatif terhadap Dividend Payout Ratio. Tanda negatif yang terdapat pada koefisien regresi menunjukkan bahwa setiap peningkatan nilai Debt to Equity Ratio akan menyebabkan menurunnya nilai Dividend Payout Ratio sebesar -0,025 satuan. Konstanta sebesar 44,807 menyatakan bahwa jika Debt to Equity Ratio bernilai konstan maka besarnya Dividend Payout Ratio adalah sebesar 44,807.

\section{Hipotesis 3}

Hasil pengujian hipotesis pada tabel 10, pengujian menunjukkan bahwa nilai t hitung sebesar 5,109 > nilai t tabel sebesar 1,7709 dan nilai signifikasi lebih besar dari 5\% yaitu sebesar $0,000 \%$ maka $\mathrm{H}_{0}$ ditolak dan $\mathrm{H}_{\mathrm{a}}$ diterima. Dapat disimpulkan bahwa Return on Asset secara parsial berpengaruh positif terhadap Dividend Payout Ratio. Tanda positif yang terdapat pada koefisien regresi menunjukkan bahwa setiap peningkatan nilai Return on Asset akan menyebabkan meningkatnya nilai Dividend Payout Ratio sebesar 0,892 satuan. Konstanta sebesar 44,807 menyatakan bahwa jika Return on Asset bernilai konstan maka besarnya Dividend Payout Ratio adalah sebesar 44,807.

\section{Pengaruh Likuiditas (Current Ratio) terhadap Dividen (Dividend Payout Ratio)}

Hasil penelitian menunjukkan bahwa Current Ratio secara parsial tidak berpengaruh terhadap Dividend Payout Ratio. Hal ini menyebabkan Current Ratio pengaruhnya tidak signifikan terhadap Dividend Payout Ratio. Tanda negatif yang terdapat pada koefisien regresi menunjukkan bahwa setiap peningkatan nilai Current Ratio akan menyebabkan menurunnya nilai Dividend Payout Ratio. Posisi Current Ratio dalam penelitian ini memiliki posisi yang tidak terlalu kuat untuk pembayaran dividen dimana Current Ratio yang dimiliki perusahaan diperhitungkan untuk membayar utang jangka pendek yang dimiliki perusahaan.

Kasmir (2014) mengemukakan bahwa apabila Current Ratio rendah maka dapat dikatakan bahwa perusahaan kurang modal untuk membayar utang. Sedangkan Mulyawan (2015) dividen merupakan arus kas keluar, semakin besar jumlah kas yang tersedia dan likuiditas perusahaan, semakin besar pula kemampuan perusahaan untuk membayar dividen. Hasil penelitian ini konsisten dengan penelitian Laim, dkk (2015) bahwa Current Ratio tidak berpengaruh terhadap Dividend Payout Ratio. 
Namun tidak konsisten dengan hasil penelitian Afrina (2014) serta Rehman dan Takumi (2012) bahwa Current Ratio berpengaruh positif signifikan terhadap Dividend Payout Ratio. Tidak konsisten dengan hasil penelitian Putri (2017) bahwa Current Ratio berpengaruh negatif signifikan terhadap Dividend Payout Ratio.

\section{Pengaruh Solvabilitas (Debt to Equity Ratio) terhadap Dividen (Dividend Payout Ratio)}

Hasil penelitian menunjukkan bahwa Debt to Equity Ratio secara parsial berpengaruh negatif terhadap Dividend Payout Ratio. Sehingga menyebabkan Debt to Eqiuty Ratio pengaruhnya signifikan terhadap Dividend Payout Ratio. Tanda negatif di koefisien regresi berarti setiap peningkatan nilai Debt to Equity Ratio akan menyebabkan menurunnya nilai Dividend Payout Ratio. Menurut teori pecking order, profitabilitas perusahaan akan semakin menurun apabila tingkat hutang mengalami peningkatan, untuk itu teori pecking order mengatakan tingkat hutang dan profitabilitas berbanding terbalik. Debt to Equity Ratio terbukti mempunyai pengaruh negatif signifikan terhadap Dividend Payout Ratio, ini membuktikan teori pecking order sesuai dengan penelitian, Debt to Equity Ratio yang semakin tinggi maka menimbulkan semakin rendah perusahaan membayar Dividend Payout Ratio diakibatkan berkurangnya laba untuk menutup hutang-hutang yang digunakan perusahaan sebagai modal usaha.

Hasil penelitian ini konsisten dengan hasil penelitian Putri (2017), Laim dkk (2015) dan Parera (2016) bahwa Debt to Equity Ratio secara parsial berpengaruh negatif dan signifikan terhadap Dividend Payout Ratio. Namun hasil penelitian ini tidak konsisten dengan hasil penelitian Rehman dan Takumi (2012) bahwa Debt to Equity Ratio secara parsial berpengaruh positif dan signifikan terhadap Dividend Payout Ratio. Tidak konsisten dengan hasil penelitian Afrina 2014), Samosir (2017), Marlina dan Danica (2009), Yunita dan Friskarunia (2016) serta Swastyastu, dkk (2014) bahwa Debt to Equity Ratio secara parsial tidak berpengaruh signifikan terhadap Dividend Payout Ratio.

\section{Pengaruh Profitabilitas (Return on Asset) terhadap Dividen (Dividend Payout Ratio)}

Hasil penelitian menunjukkan bahwa Return on Asset secara parsial berpengaruh positif terhadap Dividend Payout Ratio. Sehingga hal ini menyebabkan Retur on Asset pengaruhnya signifikan terhadap Dividend Payout Ratio. Tanda positif pada koefisien regresi menunjukkan bahwa setiap peningkatan nilai Return on Asset akan mengikuti nilai Dividend Payout Ratio yang juga meningkat.

Hasil penelitian dapat menjelaskan bahwa pengaruh positif Return on Asset terhadap Dividend Payout Ratio terbukti nilai profitabilitas perusahaan akan memberikan dampak pada peningkatan pemberian dividen yang akan dibayarkan. Tanda positif Return on Asset sesuai 
dengan teori Information Content or Signaling Hypothesis yang dikemukan oleh Miller dan Mondigliani bahwa besarnya dividen merupakan suatu sinyal kepada investor bahwa manajemen memprediksikan Performance yang menjanjikan keuntungan di masa mendatang.

Secara teori, menurut Sartono (2010) profitabilitas mencerminkan kemampuan perusahaan mendapatan keuntungan dari penjualan yang menjadi usahanya, total aktiva maupun modal sendiri. Hal ini menandakan bahwa jika profitabilitas meningkat maka dividen akan meningkat. Menurut Mulyawan (2015) berpendapat bahwa atas pengembangan perusahaan yang membutuhkan pendanaan perusahaan semakin besar, maka perusahaan hanya mampu membayar dividen yang kecil. Perusahaan Hasil penelitian ini konsisten dengan hasil penelitian Afrina (2014), Marlina dan Danica (2009), Yunita dan Friskarunia (2016), Rehman dan Takumi (2012), Putri (2017) serta Marpaung dan Hadianto (2009) menunjukkan bahwa Return on Asset mempunyai pengaruh positif dan signifikan terhadap Dividen Payout Ratio. Namun hasil penelitian ini tidak konsisten pada penelitian Laim, dkk (2015), Parera (2016), Swastyastu, dkk (2014) serta Ritha dan Koestiyanto (2013) bahwa Return on Asset tidak mempunyai pengaruh terhadap Dividen Payout Ratio.

\section{KESIMPULAN DAN SARAN}

Likuiditas (Current Ratio) secara parsial tidak berpengaruh signifikan terhadap Dividen (Dividen Payout Ratio) pada saham-saham indeks LQ45 di Bursa Efek Indonesia tahun 20112017. Hal ini berarti bahwa besar kecilnya Current Ratio tidak memberikan pengaruh yang signifikan terhadap nilai Dividen Payout Ratio. Current Ratio tidak dipertimbangkan oleh manajemen dalam pembayaran Dividen Payout Ratio dimana Current Ratio yang dimiliki perusahaan diperhitungkan untuk membayar utang jangka pendek yang dimiliki perusahaan.

Solvabilitas (Debt to Equity Ratio) secara parsial berpengaruh negatif signifikan terhadap dividen (Dividen Payout Ratio) pada saham-saham indeks LQ45 di Bursa Efek Indonesia tahun 2011-2017. Debt to Equity Ratio akan dipertimbangkan oleh manajemen dalam pembayaran Dividen Payout Ratio. Hal ini dapat diartikan bahwa penurunan nilai debt to equity ratio perusahaan maka kemampuan perusahaan dalam membayar dividen akan semakin tinggi. Penurunan maupun peningkatan hutang akan memengaruhi jumlah laba bersih yang akhirnya akan memengaruhi nilai laba ditahan, jika nilai hutang tinggi dipastikan akan memengaruhi kemampuan perusahaan untuk membagikan dividen.

Profitabilitas (Return on Asset) secara parsial berpengaruh positif signifikan terhadap dividen (Dividen Payout Ratio) pada saham-saham indeks LQ45 di Bursa Efek Indonesia tahun 2011-2017. Return on Asset akan dipertimbangkan oleh manajemen dalam pembayaran 
Dividen Payout Ratio. Hal ini mempunyai arti setiap kenaikan nilai return on asset maka akan menaikkan kemampuan perusahaan membayar dividen kepada pemegang saham. Hal ini disebabkan meningkatnya kemampuan profitabilitas perusahaan maka akan diikuti kemampuan perusahaan dalam menghasilkan laba bersih yang besar pula, yang akhirnya akan memengaruhi jumlah dividen yang akan dibagikan kepada pemegang saham.

Hasil penelitian ini dapat dijadikan rekomedasi bagi peneliti selanjutnya sebagai bukti empiris mengenai pengaruh likuiditas, solvabilitas dan profitabilitas terhadap dividen serta sebagai referensi bagi peneliti yang akan melakukan penelitian lanjutan dengan menambahkan variabel lain serta kriteria sampel penelitian yang mengklasifikasikan perusahaan sejenis serta variabel dependen yang dapat ditambahkan dengan dividen sebagai variabel intervening adalah harga saham, dengan alasan bahwa peningkatan dividen akan menarik perhatian investor untuk melakukan investasi, dengan demikian jika dividen meningkat yang berarti sesuai teori signaling hypotesis bahwa peningkatan dividen dipercayai investors ebagai pertanda bahwa perusahaan mempunyai prospek yang baik dimasa mendatang, maka akan menambah besar kepercayaan investor terhadap perusahaan. Keadaan ini akan menyebabkan kenaikan atas harga saham perusahaan. Koefisien determinasi yang hanya sebesar 34,6\% menunjukkan seluruh variabel independen mampu menerangkan variabel dependen sebesar $34,6 \%$ dan sisanya $65,4 \%$ dijelaskan oleh faktor-faktor lain. Diharapkan pada penelitian yang akan datang dapat menggunakan variabel makro ekonomi seperti tingkat bunga, kurs rupiah terhadap valuta asing, neraca pembayaran, ekspor-impor dan kondisi ekonomi lainnya. Serta memperhitungkan variabel-variabel bebas diluar rasio keuangan seperti peluang investasi, insider ownership, kondisi politik, inflasi, atau variabel lainnya.

Hasil penelitian dapat dipergunakan oleh investor dalam pertimbangan keputusan berinvestasi sehubungan dengan harapannya terhadap dividen yang akan diterima, karena informasi yang akurat diperlukan untuk mengetahui sejauh mana eratnya hubungan variabelvariabel yang menjadi penyebab pengaruhnya terhadap keuntungan yang diperoleh investor. Investor tidak terlalu memerhatikan likuiditas perusahaan karena likuiditas tidak berpengaruh signifikan terhadap dividen, namun investor harus memerhatikan tingkat solvabilitas dan profitabilitas suatu perusahaan dalam berinvestasi karena semakin rendah nilai debt to equity ratio perusahaan maka kemampuan perusahaan dalam membayar dividen akan semakin tinggi serta setiap kenaikan nilai return on asset maka akan menaikkan kemampuan perusahaan membayar dividen kepada pemegang saham.

Secara operasional, hasil penelitian diharapkan dapat mendorong perusahaan agar 
memperhatikan performa solvabilitas dan profitabilitas yang dapat memengaruhi peningkatan dividen namun tidak mengabaikan pengendalian terhadap resiko perusahaan. Perusahaan harus menjaga stabilitas dividen yang relatif stabil atau meningkat secara teratur daripada perusahaan membayar dividen dalam jumlah yang sama tetapi dengan cara yang berfluktuasi dari waktu ke waktu karena investor dapat menduga ukuran atas kinerja dan prospek perusahaan dari informasi tentang laba mendatang perusahaan melalui sinyal yang muncul dari pengumuman dividen, baik dalam hal stabilitas maupun perubahan dividen. Kenaikan dalam rasio pembayaran dividen dapat diinterpretasikan sebagai informasi bahwa perusahaan memiliki profitabilitas masa depan yang baik dan sebaliknya pengurangan dividen dianggap sebagai profitablitas perusahaan di masa depan tidak baik.

\section{REFERENSI}

Afrina, T. (2014). Pengaruh Current Ratio, DER dan ROA terhadap DPR Perusahaan Rokok di BEI. Jurnal Ilmu dan Riset Manajemen Sekolah Tinggi Ilmu Ekonomi Indonesia (STIESIA) Surabaya, 3 (9).

Ang, R. (1997). Buku Pintar Pasar Modal Indonesia. Jakarta: Mediasoft

Asnawi, S.K. dan Wijaya, C. (2005). Riset Keuangan : Pengujian-Pengujian Empiris. Jakarta: PT. Gramedia Pustaka Utama, Anggota IKAPI.

Baker, H. Kent dan Powell, Gary E (2012). Dividend Policy in Indonesia Survey : Evidence From Executives. Journal of Asia Business Studies, 6 (1), 79-92.

Baron, R.M. dan Kenny, D.A. (1986). The Moderator - Mediator Variable Distinction in Social Psychological Research: Conceptual, Strategic, and Stastistcal Consideration. Journal of Personality and Social Psychology, 51, 1173-1182.

Blocher, Edward J., David E Stout., dan Cokins, Gary. (2013). Cost Management: A Strategic Emphasis. $5^{\text {th }}$ ed. Jakarta: Salemba Empat.

Brigham, E.F. dan Joel F.H. (2014). Dasar-Dasar Manajemen Keuangan - Essentials of Financial Management. Jakarta: Salemba Empat.

Ekawati, Erni (2015). Manajemen Keuangan. Materi Pokok EKMA5205. Tangerang Selatan: Universitas Terbuka

Frankfurter, G.M. dan Wood, B.G. (2003). Dividend Policy - Theory and Practice. San Diego, USA: Academic Press..

Ghozali, M. Imam (2013). Aplikasi Analisis Multivariate Dengan Program SPSS. Semarang: Badan Penerbit Universitas Diponegoro.

Gumanti, Tatang Ary (2013). Kebijakan Dividen (Teori, Empiris dan Implikasi). Edisi Pertama. Yogyakarta: UPP STIM YKPN.

Gordon, Myron dan Lintner (1963). Optimal Investment and Financing Policy. Journal of Finance, 334.

Halim, Abdul (2015). Manajemen Keuangan Bisnis: Konsep dan Aplikasinya. Edisi Pertama. Jakarta: Mitra Wacana Media.

Hanafi, Mamduh M. dan Abdul, Halim. (2014). Analisis Laporan Keuangan. Edisi Keempat. Cetakan Ketiga. Yogyakarta: UPP STIM YKPN.

Indriantoro, N. dan Supomo, B. (2002). Metodologi Penelitian Bisnis untuk Akuntansi dan Manajemen. Edisi Pertama, Yogjakarta: BPFE

Kasmir (2014). Analisis Laporan Keuangan. Cetakan ke-7. Jakarta: Penerbit PT Raja Grafindo Persada. 
Laim, W. Nagoy, S. Murni, S (2015). Analisis Faktor-Faktor yang Mmepengaruhi Dividend Payout Ratio pada Perusahaan yang Terdaftar di Indeks LQ45 Bursa Efek Indonesia Jurnal EMBA Fakultas Ekonomi dan Bisnis Jurusan Manajemen Universitas Sam Ratulangi Manado, 3 (1), 1129-1140.

Marlina, L. dan Danica, C. (2009). Analisis Pengaruh Cash Position, Debt to Equity, dan Return on Assets Terhadap Dividend Payout Ratio. Jurnal Manajemen Bisnis FE USU, $2(1)$.

Marpaung, E.I. dan Hadianto, B. (2009). Pengaruh Profitabilitas dan Kesempatan Investasi terhadap Kebijakan Dividen: Studi Empirik pada Emiten Pembentuk Indeks LQ45 di Bursa Efek Indonesia, Jurnal Akuntansi Universitas Kristen Maranatha Bandung, 1 (1), 70-84.

Mulyawan, Setia (2015). Manajemen Keuangan, Bandung: Pustaka Setia.

Murthal, Haryana (2017). Meta Analysis of Dividend Policy Affect on Share Price Volatility. Asian Journal of Research in Banking and Finance, 7 (5), 242-254.

Myers. Marcus. Brealey. (2008). Dasar-dasar Manajemen Keuangan Perusahaan. Jakarta: Penerbit: Erlangga.

Parera, D. (2016). Pengaruh Profit Margin (NPM), Return on Asset (ROA), dan Debtto Equity Ratio (DER) terhadap Dividend Payout Ratio (DPR) pada Perusahaan yang Tercatat Dalam Indeks LQ45 di BEI Periode 2009-2013. Jurnal EMBA Universitas Sam Ratulangi Manado, 4 (2), 538-548.

Putri, Agnes Kartika AP. (2017). Analisis Pengaruh Return on Assets (ROA), Net Profit Margin (NPM), Current Ratio (CR) dan Debt to Equity Ratio (DER) Terhadap Dividend Payout Ratio (DPR) pada Perusahaan yang Tercatat Dalam Index LQ45 di BEI Periode 2012-2015. Jurnal Simki-Economic Universitas Nusantara PGRI Kediri, 1 (5).

Rehman, A. dan Takumi, H. (2012). Determinants of Dividend Payout Ratio : Evidence From Karachi Stock Exchange (KSE). Journal of Contemporary Issues in Busines Research. Copyright of the Academic Journals JCIBR, 1 (1), 20-27.

Ritha, H. dan Koestiyanto, E. (2013). Faktor-Faktor yang Memengaruhi Dividend Payout Ratio (DPR). e-Jurnal Manajemen dan Bisnis, 1 (1).

Salim, Ubud. (2011). Manajemen Keuangan Strategik. UB Press. Malang.

Samosir, H. (2017). Pengaruh CashRatio, Debtto Equity Ratio, dan Earning Per Share Terhadap Dividend Payout Ratio pada Perusahaan LQ45 yang Terdaftar di Bursa Efek Indonesia. Jurnal Mutiara Akuntansi Universitas Prima Indonesia. 2 (2).

Sartono, Agus (2010). Manajemen Keuangan Teori dan Aplikasi. Edisi Keempat. Cetakan ketujuh. Yogyakarta: BPFE.

Sawir, Agnes (2001). Analisis Kinerja Keuangan dan Perencanaan Keuangan. Jakarta: PT. Gramedia Pustaka Utama.

Sjahrial, Dermawan (2002). Pengantar Manajemen Keuangan. Edisi 2, Jakarta: Mitra Wacana Media.

Sugiyono (2008). Metode Penelitian Kuantitatif Kualitatif dan R\&D. Bandung: CV Alfabeta.

Swastyastu, M.W. Yuniarta, G.A. dan Atmaja, A.T. (2014). Analisis Faktor-Faktor yang Memengaruhi Kebijakan Dividend Payout Ratio yang Terdaftar di Bursa Efek Indonesia (BEI). e-Journal Si Ak Universitas Pendidikan Ganesha, 2 (1).

Syafri (2008). Analisa Kritis atas Laporan Keuangan. Jakarta: PT. Raja Grafindo Persada.

Tandelilin, Eduardus. (2010). Portofolio dan Investasi-Teori dan Aplikasi.Yogyakarta: Kanisius.

Yunita, N.A. dan Friskarunia, N. (2016). Pengaruh Kebijakan Hutang, Earning Per Share, Net Profit Margin dan Profitabilitas terhadap Dividend Payout Ratio pada Perusahaan yang Terdaftar di LQ45 Periode 2010-2014. Jurnal Akuntansi dan Keuangan Universitas Malikussaeh, 4 (1). 
Wasis. (1983). Pembelanjaan Perusahaan. Salatiga: Universitas Kristen Satya Wacana.. www.idx.co.id - LQ45 Index Constituents for the period of 2011-2017. 